\title{
酸素酸イオンを含む高温水溶液中のステンレス鋼の アノード溶解挙動と応力腐食割れ感受性*
}

\author{
柘 植 宏 之**, 薄木智 亮**, 長 野 博 夫** \\ ** 住友金属工業株式会社中央技術研究所
}

\begin{abstract}
Anodic Dissolution Behavior and Stress Corrosion Cracking of
SUS 304 Stainless Steel in High Temperature Water and Chloride Solutions Containing Oxyanions*
\end{abstract}

\author{
Hiroyuki Tsuge**, Noriaki Usuki** and Hiroo Nagano** \\ **Central Research Laboratories, Sumitomo Metal Industries, Ltd.
}

\begin{abstract}
Relationship between anodic polarization behavior and stress corrosion cracking (SCC) susceptibility of SUS 304 stainless steel has been studied in both high temperature water and chloride solutions containing oxyanions such as $\mathrm{MoO}_{4}{ }^{2-}, \mathrm{WO}_{4}{ }^{2-}, \mathrm{CrO}_{4}{ }^{2-}$ and $\mathrm{VO}_{3}{ }^{-}$. Results obtained are as follows:

1) Intergranular stress corrosion cracking (IGSCC) of sensitized SUS 304 stainless steel in water at $250^{\circ} \mathrm{C}$ occurred at the potential range where $\mathrm{Cr}$ depleted zones along grain boundaries dissolve more rapidly than the matrix, e.x., above $-100 \mathrm{mV}$ (vs. $\mathrm{Ag} / \mathrm{AgCl}$ ) in the constant load SCC test.

2) Addition of the oxyanions more than $3 \times 10^{-2} \mathrm{M}$ suppresses completely the IGSCC of sensitized SUS 304 stainless steel. The IGSCC inhibition by $\mathrm{MoO}_{4}{ }^{2-}$ seems to be achieved by decreasing the dissolution rate of $\mathrm{Cr}$ depleted zones to the level of the matrix owing to the formation of chromium rich oxide film.

3) Addition of the oxyanions more than $2 \times 10^{-2} \mathrm{M}$ suppresses completely the transgranular stress corrosion cracking [TGSCC] of SUS 304 stainless steel in high temperature water containing $\mathrm{Cl}^{-}$. $\mathrm{MoO}_{4}{ }^{2-}$ makes the corrosion potential of SUS 304 stainless steel in the solution with $\mathrm{MoO}_{4}{ }^{2-}$ more negative than in the solution without $\mathrm{MoO}_{4}{ }^{2-}$ and strengthens the surface oxide film rich in chromium oxide enough to resist $\mathrm{Cl}^{-}$attack.
\end{abstract}

\section{1. 緒言}

ステンレス鋼に Mo 添加すると中性の 塩化物溶液中 での孔食あるいは吵間腐食に対する抵抗性が増加するこ とは良く知られている ${ }^{1) ~}$ む環境中での耐局部腐食性を向上させる目的で種々の Mo 含有ステンレス鋼が開発されている。

鋼中の Mo の耐局部腐食性向上の機構としては二つの 機構が提案されている。その一つは不働態皮膜説で, Mo が酸化モリブデンあるいはモリブデン酸鉄などの化合物

* 第 29 回 腐食防食討論会で発表 (於 名古屋・ 愛知県産業貿易館西館)

** 个660 尼崎市西長洲本通 1-3 (1-3, Nishinagasu Hondori, Amagasaki, 660 Japan)
として鋼表面酸化皮膜中に濃縮することによって耐食性

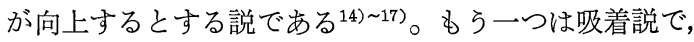
溶液中にイオンとして溶出したモリブデン酸イオンが, 鋼表面に吸着し局部腐食を防止する説である ${ }^{18), 19) 。 ~}$ またモリブデン酸イオン，クロム酸イオンあるいはタ ングステン酸イオン等の酸素酸イオンは冷却器等に用い られる鋼の腐食に対するインヒビターとして実用化され ている20),21)。しかしこれらの酸素酸イオンが使用され る温度は主として $100^{\circ} \mathrm{C}$ 以下であり, 高温水中のステ ンレス鋼の応力腐食割れに対する効果についてはほとん ど報告が無い。

高温水中のステンレス鋼の応力腐食割れの研究におい て, Mo 含有ステンレス鋼の耐応力腐食割れ性が良好で 
あることが明らかとなってきた。そこでその機構の解明 並びに環境側からの SCC 防止の対策の一つとして, 高 温水中のステンレス鋼の応力腐食割れに対するモリブデ ン酸イオンあるいはその他の酸素酸イオンの影響につい て, これらのイオンを含む高温水溶液中のアノード分極 挙動之粒界応力腐食割れ (IGSCC) 並びに $\mathrm{Cl}^{-}$イオン 含有高温水溶液中のアノード分極挙動と粒内応力腐食割 れ (TGSCC) そついて調查した。

\section{2. 実 験 法}

\section{1 供 試 材}

本研究に用いた合金の化学成分を Table 1 と示す。

Table 1 中の $\mathrm{Cr}$ 変化材の $\mathrm{Fe}-x \mathrm{Cr}-11 \mathrm{Ni}$ 材 $(x=8$, 12） 304 ステンレス鋼の鋭敏化材の粒界 $\mathrm{Cr}$ 欠乏層 を想定した合金である。Cr 変化材は $17 \mathrm{~kg}$ の真空炉で

Table 1 Chemical composition of alloys used (wt \%).

\begin{tabular}{|c|c|c|c|c|c|c|c|}
\hline Steel & C & $\mathrm{Si}$ & $M n$ & $p$ & S & $\mathrm{Ni}$ & $\mathrm{Cr}$ \\
\hline SUS 304 & 0.052 & 0.52 & 1.73 & 0.027 & 0.005 & 9.75 & 18.9 \\
\hline Lab. steel A & 0.003 & 0.49 & 1.51 & 0.002 & 0.004 & 11.2 & 8.0 \\
\hline B & 0.004 & 0.45 & 1.48 & 0.002 & 0.003 & 11.6 & 12.0 \\
\hline c & 0.004 & 0.53 & 1.48 & 0.002 & 0.004 & 11.5 & 18.0 \\
\hline
\end{tabular}

溶製後鍛造し，厚さ $7 \mathrm{~mm}$ なで熱延後，厚さ $4.9 \mathrm{~mm}$ まで泠延し，溶体化熱処理として $1,100^{\circ} \mathrm{C} \times 30 \mathrm{~min}$ 水 冷を施し，所定の試験を作製した。

SUS 304 鋼は市販の 4 インチパイプ (外径 $114 \phi \times$ 厚 さ 8.6 $6^{t}$ を使用した。溶体化熱处理は $1,060^{\circ} \mathrm{C} \times 2 \mathrm{~min}$ 水冷であり, その後鋭敏化処理として $650^{\circ} \mathrm{C} \times 3,30 \mathrm{~h}$ 空冷を施し，所定の試験片を作製した。

\section{2 実 験 法}

\subsection{1 高温水中の分極測測定}

高温水中の分極測定には試験片として $15^{\phi} \times 3^{t}$ の形状 を用い，試料表面は湿式 600 番で仕上げた。オートク レーブは内容積 $4 l$ の Alloy 600 内張の 316 製オー トクレーブを用いた。照合電極としては, $0.1 \mathrm{MKCl}$ の 電解液を持つ $\mathrm{Ag} / \mathrm{AgCl}$ 内部照合電極を使用し, 対極は Pt を使用した。試験液としては純水の場合は電気伝導 度を与兄るために濃度 $0.05 \mathrm{M} \mathrm{Na}_{2} \mathrm{SO}_{4}$ 溶液を使用し, 酸素酸イオンを添加した純水の場合はそのまま試験液と して使用した。溶液の脱気は $80^{\circ} \mathrm{C}$ まで溶液温度を上昇 し Ar ガスによって行った。分極測定は $250^{\circ} \mathrm{C}$ (昇温時 間 $3 \mathrm{~h})$ 亿安定し, 更に試験片の腐食電位 $\left(E_{\mathrm{corr}}\right)$ が安 定する (昇温後 $30 \mathrm{~min}$ ) を待って開始した。電位掃引速 度は $20 \mathrm{mV} / \mathrm{min}$ を使用した。

また $\mathrm{Cl}^{-}$含有高温水中の分極測定には内容積 $3 l$ の
ハステロイ製オートクレーブを用い, 試験片, 照合電 極, 対極は高温純水の場合と同じものを使用した。試験 液としては電気伝導度 $0.1 \mu \mathrm{S} / \mathrm{cm}$ 以下の脱イオン水に $\mathrm{NaCl}$ を所定量添加した $1,000 \mathrm{ppm} \mathrm{Cl}$-イオン溶液を使 用し，その溶液に酸素酸イオンを添加して用いた。分極 測定の温度は $200^{\circ} \mathrm{C}$ で行い, $\mathrm{Ar}$ 脱気, 電位掃引速度は 高温純水の場合と同でである。純水及び $\mathrm{Cl}^{-}$イオン含 有水中に添加した酸素酸イオンとしては $\mathrm{MoO}_{4}{ }^{2}, \mathrm{VO}_{3}{ }^{-}$, $\mathrm{WO}_{4}{ }^{2-}, \mathrm{CrO}_{4}{ }^{2-}$ イオンをナトリウム塩の形で添加した。

\subsection{2 高温水溶液中の SCC 試験}

\section{a) 定電位定負荷 SCC 試験}

定電位定負荷 SCC 試験には平行部 $20^{l} \times 3 \mathrm{~mm}^{\phi}$ の 形状の試験片を使用した。表面仕上げは乾式 320 番で行 った。試験溶液は $0.05 \mathrm{M} \mathrm{Na}_{2} \mathrm{SO}_{4}$ 溶液を用い, 応力の 負荷方法としては差圧方式を用い，外部シリンダーに $\mathrm{N}_{2}$ ガスを注入し, オートクレーブ内部の蒸気压との

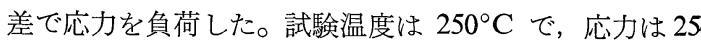
$\mathrm{kg} / \mathrm{mm}^{2}$ で試験を実施した。SCC 感受性の評価は応力 腐食割机破断時間を測定することにより行った。

\section{b) SSRT 試験 (Slow Strain Rate Test)}

SSRT 試験には平行部 $20^{t} \times 2^{w} \times 2^{t}(\mathrm{~mm})$ の形状の試 験片を使用した。表面仕上げは乾式 320 番で行った。試 験溶液は純水及び酸素酸イオンを添加した溶液を用い, イオン濃度 $3 \times 10^{-5} \mathrm{M}(\mathrm{g}$ イオン $/ l) \sim 3 \times 10^{-1} \mathrm{M}$ である。 SSRT 試験は温度 $250^{\circ} \mathrm{C}$, 溶存素素 $36 \mathrm{ppm}$ (酸素飽和) で歪速度 $4.17 \times 10^{-6} / \mathrm{s}$ で実施した。SCC 感受性の評価 は試験後の SCC 破面率を測定することによって行っ た。

\section{c）シングルUベンド SCC 試験}

シングルUベンド SCC 試験には $75^{l} \times 10^{w} \times 2^{t}$ の形 状のUベンド試験片を用い, 試験片表面は湿式 600 番で 仕上げた。試験条件は温度 $200^{\circ} \mathrm{C}$, 大気飽和 (溶存酸素 $8 \mathrm{ppm}$ ) 浸漬時間は $500 \mathrm{~h}$ である。試験溶液としては $1,000 \mathrm{ppm} \mathrm{Cl} \mathrm{Cl}^{-}$イオン $(\mathrm{NaCl}$ で調整) 溶液を用い, 酸素 酸イオンを添加して実験を行った。イオン濃度は $2 \times$ $10^{-4} \mathrm{M} \sim 2 \times 10^{-1} \mathrm{M}$ を用いた。 SCC 感受性の評価とし ては試験片中央縦断面に和ける最大応力腐食割れ長さを 測定することにより行った。

\section{d) 皮膜分析}

高温水中の表面皮膜分析としては，表面を湿式 1200 番仕上げを施した $12^{l} \times 8^{w} \times 1^{t}$ の形状の試験片を用い た。試験片はオートクレーブから取り出した後, 純水で 洗浄し, 乾燥させた。表面分析は IMMA (Ion Microprobe Mass Analyser) 及び ESCA (Electron Spectroscopy for Chemical Analysis) を用いて行った。 


\section{3. 実験結果}

3.1 高温水溶液中のステンレス 鋼の粒界応力腐食割 れ(IGSCC)に及ほす酸素酸イオンの影響

3.1 .1 高温水溶液中のステンレス 鋼のアノード溶解 挙動之 IGSCC

304 系の $\mathrm{Cr}$ 変化村の $0.05 \mathrm{M} \mathrm{Na}_{2} \mathrm{SO}_{4}$ 溶液中のア， 一ド分極曲線を Fig. 1 に示す。SUS 304 鋼で惊腐食電 位 $E_{\text {corr }}$ は $-750 \mathrm{mV}$ (v.s. $\mathrm{Ag} / \mathrm{AgCl}$ ) である。不働態 電位領域は $-600 \mathrm{mV} \sim 0 \mathrm{mV}$ に西り不働態保持電流密 度は $10 \mu \mathrm{A} / \mathrm{cm}^{2}$ である。過不㗢態ピークは $100 \mathrm{mV}$ 付 近に出現する。Fig. 1 に示したアノード分極曲線に护

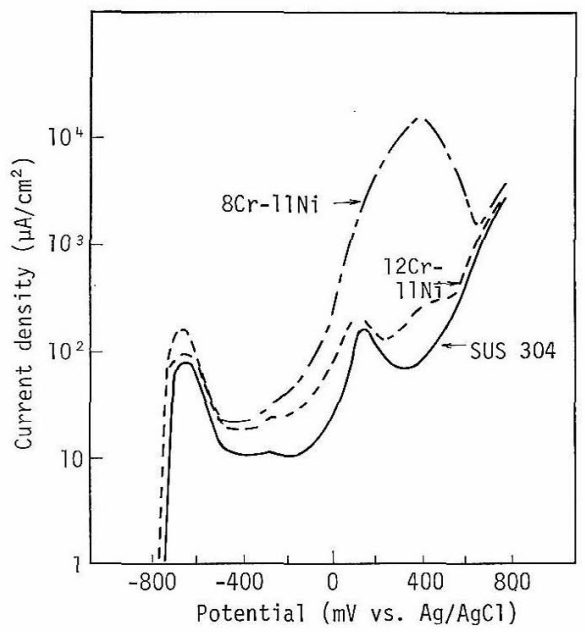

Fig. 1 Anodic polarization curves for SUS 304 stainless steel and $\mathrm{Fe}-\mathrm{xCr}-11 \mathrm{Ni}$ alloys in deaerated water with $5 \times 10^{-2} \mathrm{M} \mathrm{Na}_{2} \mathrm{SO}_{4}$ at $250^{\circ} \mathrm{C}$ at a scanning rate of $20 \mathrm{mV} / \mathrm{min}$.

いて粒界 $\mathrm{Cr}$ 欠乏層を想定した $12 \mathrm{Cr}-11 \mathrm{Ni}$ 村及び 8 $\mathrm{Cr}-11 \mathrm{Ni}$ 材の不働態領域での電流密度は SUS 304 銅の 值に比較して 3 倍程度高い。

SUS 304 鋼の鋭敏化材の定電位定負荷 SCC 試験結果 を Fig. 2 飞示す。Fig. 2 から明らかなよ5に, SUS 304 鋼の鋭敏化材 $\left(650^{\circ} \mathrm{C} \times 30 \mathrm{~h}\right)$ は $-100 \mathrm{mV}$ (vs. $\mathrm{Ag} / \mathrm{AgCl})$ 以上で IGSCC を発生する。印加電位を上昇 させると，IGSCCによる破断時問は長時問側に移行し， $-100 \mathrm{mV}$ 付近の破断時間が最小である。試験後の破面 の SEM 観察結果を Fig. 3 飞示す。破面は完全な粒界 态力腐食割れ破面を示し, 印加電位が高電位側になるに つれて粒界応力腐食割れ破面率は減少する。

この結果を Fig. 1 のアノード分極挙動と比較する そ, SUS 304 鋼の IGSCC の発生が開始される電位 $(-100 \mathrm{mV})$ は $8 \mathrm{Cr}-11 \mathrm{Ni}$ 材及び $12 \mathrm{Cr}-11 \mathrm{Ni}$ 材が SUS 304 鋼比此較して不働態保持電流密度が急激に增加 する。このため SUS 304 鋼の鋭敏化材の Cr 久乏層の

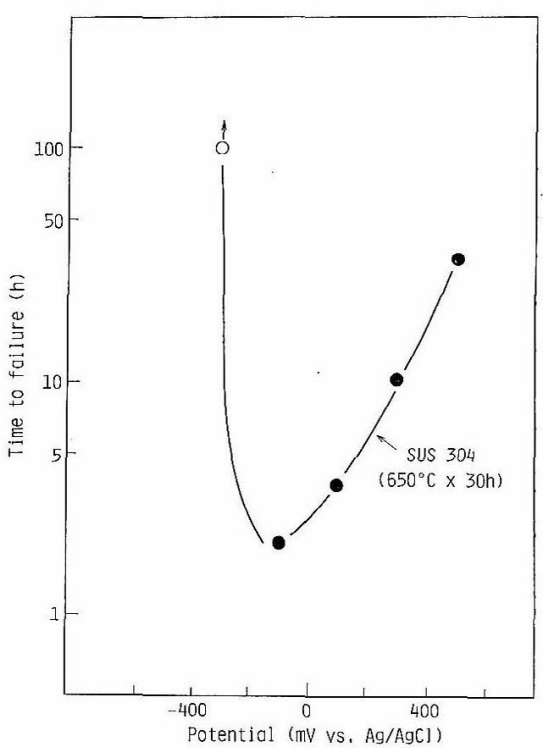

Fig. 2 Potentiostatic constant load SCC test result of SUS 304 stainless steel in water at $250^{\circ} \mathrm{C}$ with $5 \times 10^{-2} \mathrm{Na}_{2} \mathrm{SO}_{4}$ under a tensile stress of $25 \mathrm{kgf} / \mathrm{mm}^{2}$ (air-saturated).

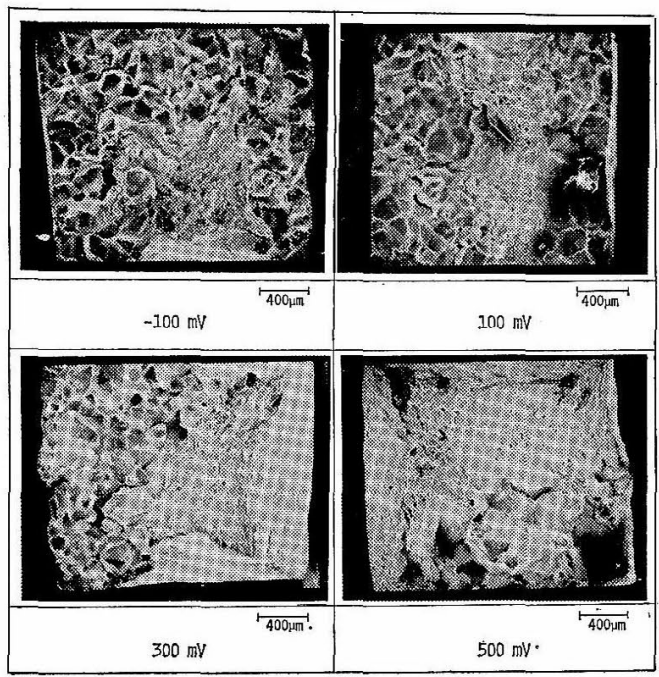

Fig. 3 SEM of SUS 304 stainless steel specimen fracture surfaces after potentiostatic constant load SCC tests at different potentials. (Specimen $650^{\circ} \mathrm{C} \times 30 \mathrm{~h}$, solution $5 \times 10^{-2}$ $\mathrm{M} \mathrm{Na} \mathrm{Na}_{4}, 250^{\circ} \mathrm{C}$, stress $25 \mathrm{kgf} / \mathrm{mm}^{2}$ )

溶解が，この電位以上で増加することが IGSCC 発生 の原因と考兄られるな技非脱気の $E_{\text {corr }}$ は $-300 \mathrm{mV}$ (vs. $\mathrm{Ag} / \mathrm{AgCl}$ ) であり, この電位の定負荷試験（ h) では IGSCC は発生しない。SSRT 試験では非脱気 の場合の $E_{\mathrm{corr}}$ は $-500 \mathrm{mV}$ 付近にあり,この場合は SUS 304 鋼鋭敏化材は IGSCC を発生する。SSRT 試 験では機械的に皮膜を破壊するため $E_{\mathrm{corr}}$ は低くなり， 
また SSRT 試験での IGSCC 発生電位領域は定負荷 $\mathrm{SCC}$ 試験より広く, 少なくとも $-500 \mathrm{mV}$ 以上の領域 で IGSCC を発生すると考光られる。SSRT 試験におい て $E_{\mathrm{corr}}$ の $-500 \mathrm{mV}$ で鋭敏化 SUS 304 鋼が IGSCC を発生する原因としては，Fig. 1 で示した応力を付加 しない $\mathrm{Cr}$ 変化材と SUS 304 鋼の不働態保持電流密度の 若干の差が皮膜破壊によって拡大されることが IGSCC 発生の原因となると考光られる。

な招 $\mathrm{Na}_{2} \mathrm{SO}_{4}$ を添加した溶液での鋭敏化 SUS 304 鋼 の SCC 感受性は純水飞比較し若干高くなるが， SCC 発生電位には注とんど影響がないと考兄られる。

\subsection{2 酸素酸イオンを含む高温水溶液中のアノード 溶解挙動と IGSCC}

高温水中の鋭敏化ステンレス鋼のIGSCC の研究にお いて, Mo 含有ステンレス鋼の耐 SCC 性が良好である ことが明らかとなっており，鋼中に含まれる Mo は高 温水中にモリブデン酸イオンとして溶出すると考兄られ る。そこでその機構の解明並びそ環境側からの SCC 防 止について検討するために, 高温水中にモリブデン酸イ オンを含む各種酸素酸イオンを添加して, 鋭敏化 SUS 304 鋼のIGSCC 挙動を調查した。

SUS 304 鋼の高温水中のIGSCC に及ぼす酸素酸イ オンの影響を Fig. 4 と示す。Fig. 4 はSSRT 試験の

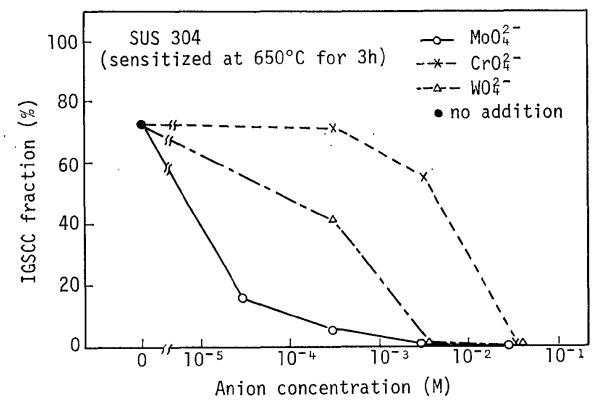

Fig. 4 Effect of oxyanions on the IGSCC inhibition of sensitized SUS 304 stainless steel (SSRT method; solution $250^{\circ} \mathrm{C}$, D.O. 36 $\mathrm{ppm}$, strain rate $4.2 \times 10^{-6} / \mathrm{s}$ ).

結果で, 縦軸は SSRT 試験後の試験片の IGSCC 破面 率である。破面率は全破面の面積中の IGSCC の破面の 面積の割合をSEM 観察によって測定して求めた。イオ ンを添加しない場合の鋭敏化 SUS 304 鋼 $\left(650^{\circ} \mathrm{C} \times 3 \mathrm{~h}\right)$ の IGSCC 破面率は約 70\%を示すが，イオンの添加を 行うと IGSCC 破面率は減少する。完全に IGSCC が抑 制される酸素酸イオン濃度は $\mathrm{MoO}_{4}{ }^{2-}, \mathrm{WO}_{4}{ }^{2-}, \mathrm{CrO}_{4}{ }^{2-}$ イオンのいずれも $3 \times 10^{-2} \mathrm{M}$ である。添加した酸素酸 イオンの内で鋭敏化 SUS 304 鋼の IGSCC 防止効果の 大きい順は $\mathrm{MoO}_{4}{ }^{2-}>\mathrm{WO}_{4}{ }^{2-}>\mathrm{CrO}_{4}{ }^{2-}$ の順である。

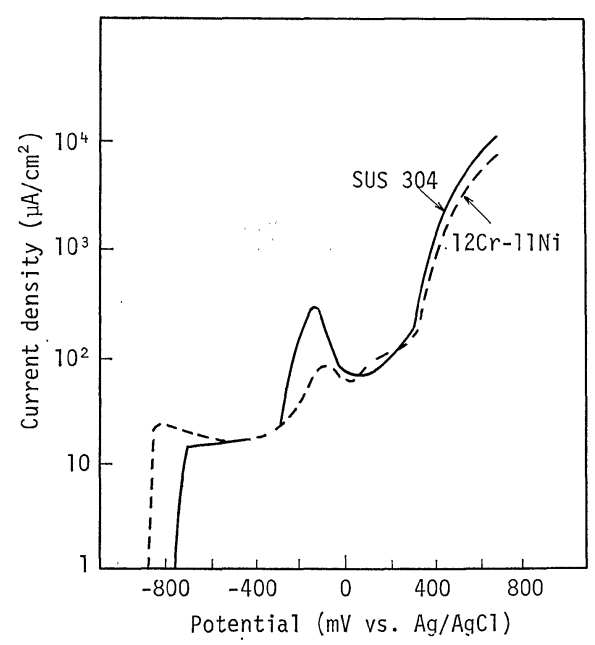

Fig. 5 Anodic polarization curves for SUS 304 stainless steel and Fe-12 Cr-11 Ni alloy in deaerated water with $3 \times 10^{-2} \mathrm{M} \mathrm{MoO}_{4}{ }^{2-}$ at $250^{\circ} \mathrm{C}$ at a scanning rate of $20 \mathrm{mV} / \mathrm{min}$.

次に $\mathrm{MoO}_{4}{ }^{2-}$ イオンによる IGSCC 防止機構を検討 するため $3 \times 10^{-2} \mathrm{M} の \mathrm{MoO}_{4}{ }^{2-}$ イオン含有高温水溶液 中での SUS 304 鋼及び $12 \mathrm{Cr}-11 \mathrm{Ni}$ 材のアノード分極 曲線を調查した結果を Fig. 5 亿示す。 $\mathrm{MoO}_{4}{ }^{2-}$ 含有溶 液中では $-800 \mathrm{mV}$ (vs. $\mathrm{Ag} / \mathrm{AgCl}$ ) 付近飞ある活性溶 解の電流密度のピークが消隇すること, をた $-150 \mathrm{mV}$ 付近に皮膜の生成に関連すると考兄られる過不働態溶解 の電流密度のピークが出現する。 $\mathrm{MoO}_{4}{ }^{2-}$ イオン含有溶 液中のアノード分極曲線と SSRT 試験の結果を比較す ると, SSRT 試験での $E_{\text {corr }}$ である $-500 \mathrm{mV}$ 付近で $\mathrm{Cr}$ 欠乏層相当材である $12 \mathrm{Cr}-11 \mathrm{Ni}$ 材の溶解が抑制さ れ粒内相当材である SUS 304 鋼の不働態電流密度とほ ぼ等しくなることが, $\mathrm{MoO}_{4}{ }^{2-}$ イオン含有溶液中での鋭

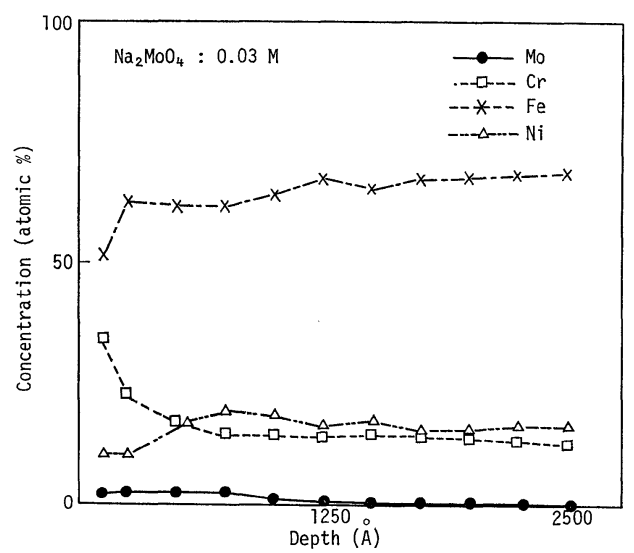

Fig. 6 IMMA analyses of the surface film of 304 stainless steel in water with $3 \times 10^{-2} \mathrm{M}$ $\mathrm{Na}_{2} \mathrm{MoO}_{4}$ at $250^{\circ} \mathrm{C}$. 
敏化 SUS304 鋼のIGSCC 防止の原因であると考兄ら れる。

$\mathrm{MoO}_{4}{ }^{2-}$ イオン含有溶液中の SUS 304 鋼の表面皮膜 の IMMA 分析結果を Fig. 6 飞示す。溶液界面近傍の 表面皮膜中に $\mathrm{Mo}$ の存在が確認でき，末た $\mathrm{Cr}_{2} \mathrm{O}_{3}$ の含有 量は高い。添加 $\mathrm{MoO}_{4}{ }^{2-}$ イオン濃度の上昇に伴って表 面皮膜の膜厚は減少する。この結果は SUS 304 鋼の表 面での腐食が抑制され，Moの表面吸着あるいは酸化物 として表面皮膜内に微量 Mo が存在することによって 緻密な皮膜が形成されることを示していると考兄られ る。

\section{2 高温水溶液中の ステンレス 鋼の粒内応力腐食割 れ（TGSCC）に及ぼす酸素酸イオンの影響}

\subsection{1 $\mathrm{Cl}^{-}$含有高温水溶液中のステンレス鋼のアノ 一ト溶解挙動と TGSCC}

$\mathrm{Cl}^{-}$含有高温水溶液中でのステンレス鋼の TGSCC 挙動を検討するため, シングルUベンド SCC 試験で比 較的短時間で TGSCC が発生する厳しい条件として, $200^{\circ} \mathrm{C}, 1,000 \mathrm{ppm} \mathrm{Cl}^{-}$含有高温水を用いた。SUS 304 鋼の $200^{\circ} \mathrm{C}, 1,000 \mathrm{ppm} \mathrm{Cl}^{-}$イオン含有水中のアノード 分極曲線を Fig. 7 飞示す。脱気条件での $E_{\text {corr }}$ は $-750 \mathrm{mV}$ (vs. $\mathrm{Ag} / \mathrm{AgCl}$ ) であり, 孔食発生電位 (電流 密度 $100 \mu \mathrm{A} / \mathrm{cm}^{2}$ を呈する電位) は $-150 \mathrm{mV}$ である。 非脱気の溶存酸素 $8 \mathrm{ppm}$ の条件では, $E_{\mathrm{corr}}$ は $-220 \mathrm{mV}$ で孔食発生電位に近く, アノード分極曲線上で法不働態 領域は存在せず，孔食を発生して，直ちに電流密度は上 昇する。Table 2 は定電位シングルUベンド SCC 試験

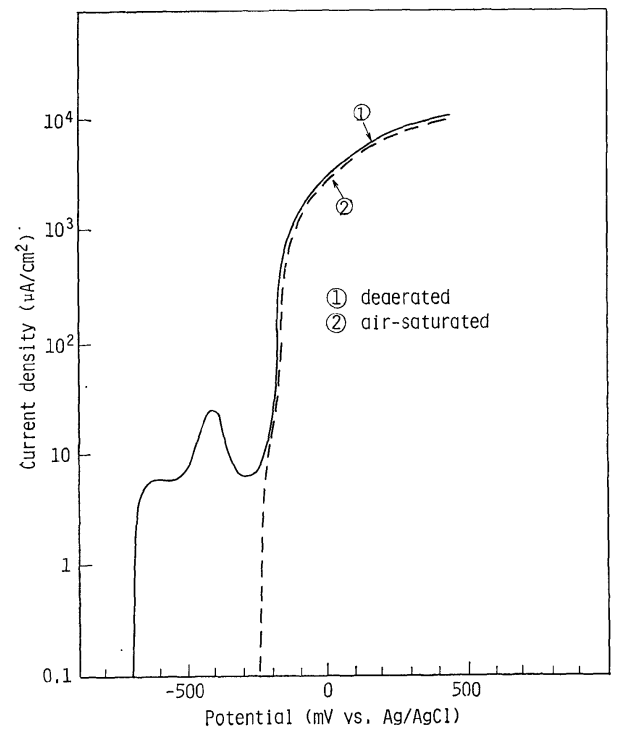

Fig. 7 Anodic polarization curves for SUS 304 stainless steel in water containing $1000 \mathrm{ppm}$ $\mathrm{Cl}^{-}$at $200^{\circ} \mathrm{C}$ at a scanning rate of $20 \mathrm{mV} /$ $\min$.
Table 2 Potentiostatic SCC test results of SUS 304 stainless steel in $1,000 \mathrm{ppm} \mathrm{Cl}^{-}$containing water at $200^{\circ} \mathrm{C}$ (air-saturated, U-bend).

\begin{tabular}{|c|c|c|c|c|c|}
\hline $\begin{array}{l}\text { Applied potential } \\
\text { Solution }\end{array}$ & $\begin{array}{c}-700 \mathrm{mV} \\
\text { for } 500 \mathrm{~h} \\
\end{array}$ & $\begin{array}{c}-220 \mathrm{mV} \\
\text { for } 500 \mathrm{~h} \\
\end{array}$ & $\begin{array}{c}0 \mathrm{mV} \\
\text { for } 90 \mathrm{~min}\end{array}$ & $\begin{array}{c}250 \mathrm{mV} \\
\text { for } 30 \mathrm{~min} \\
\end{array}$ & $\begin{array}{c}500 \mathrm{mV} \\
\text { for } 20 \mathrm{~min} \\
\end{array}$ \\
\hline $\begin{array}{l}1000 \mathrm{ppm} \mathrm{Cl} \\
\text { containing water }\end{array}$ & no $S C C$ & \begin{tabular}{|l|} 
TGSCC \\
$820 \mu$ \\
\end{tabular} & $\begin{array}{l}\text { TGSCC } \\
1700 \mu\end{array}$ & $\begin{array}{l}\text { TGSCC } \\
1300_{\mu}\end{array}$ & $\begin{array}{l}\text { TGSCC } \\
1000_{\mu}\end{array}$ \\
\hline
\end{tabular}

結果を示す。試験時間は非脱気の条件下の $E_{\mathrm{corr}}(-220$ $\mathrm{mV})$ 飞和故電流密度 $8 \mu \mathrm{A} / \mathrm{cm}^{2}$ から $500 \mathrm{~h}$ の自然浸 漬 SCC 試験を実施した時の電気量を計算して, 同一の 電気量になるように各電位での保持時間を計算した。 $1,000 \mathrm{ppm} \mathrm{Cl}^{-}$イオン溶液中では非脱気の条件での $E_{\text {corr }}(-220 \mathrm{mV})$ 以上で SUS 304 鋼は $1,000 \mu$ 程度の TGSCC を発生した。

この結果をFig. 7 のアノード分極曲線と比較すると, SUS 304 鋼の TGSCC の発生が開始される電位は孔食 発生電位とほぼ一致して招り，TGSCC の起点となる孔 食が発生することが TGSCC 発生の要因であると考克 られる。

\subsection{2 酸素酸イオンを含む高温水溶液中のアノート 溶解挙動と TGSCC}

$\mathrm{Cl}^{-}$イオン含有中性溶液中では Mo 含有ステンレス 鋼は孔食発生の抵抗性が高いことが知られている。孔食 は TGSCC の起点になり得ること， また鋼中 Moは モリブデン酸イオンとして溶出すると考光られるため, TGSCC の機構の解明並びに環境側からの SCC 防止に ついて検討する目的で, 高温水中にモリブデン酸イオン を含む各種酸素酸イオンを添加して溶体化 SUS 304 鋼 の TGSCC 挙動を調查した。

SUS 304 鋼の高温水中の TGSCC に及ぼす酸素酸イ オンの影響を Fig. 8 亿示す。Fig. 8 はSUS 304 鋼の溶 体化処理材のシングルUベンド SCC 試験結果で, 縦軸 は最大 TGSCC 深さである。酸素酸イオン無添加の $200^{\circ} \mathrm{C}$, 非脱気, $1,000 \mathrm{ppm} \mathrm{Cl}-$ イオン溶液中 $500 \mathrm{~h}$ の

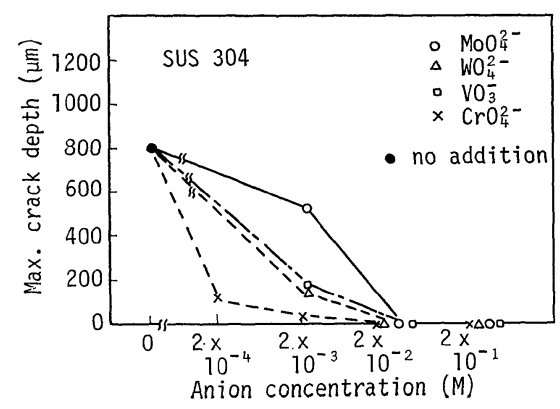

Fig. 8 Effect of oxyanions on the TGSCC inhibition of SUS 304 stainless steel (U-bend specimen, $1000 \mathrm{ppm} \mathrm{Cl}^{-}$, D.O. $8 \mathrm{ppm}$, $200^{\circ} \mathrm{C}, 500 \mathrm{~h}$ ). 


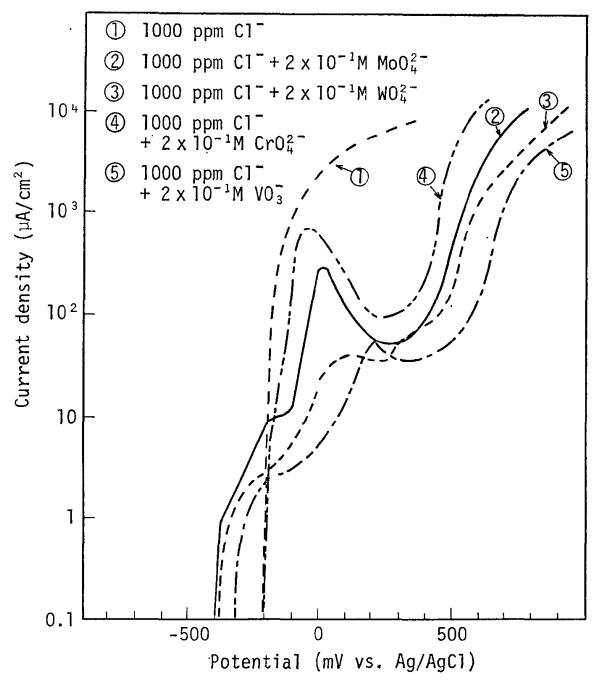

Fig. 9 Effect of oxyanions on the anodic polarization curves for SUS 304 stainless steel in air-saturated water containing $1000 \mathrm{ppm}$ $\mathrm{Cl}^{-}$at $200^{\circ} \mathrm{C}$ at a scanning rate of $20 \mathrm{mV} /$ $\min$.

SCC 試験では SUS 304 鋼は $800 \mu$ の TGSCC を生ず るが，酸素酸イオンを添加すると TGSCC 感受性は減 少する。SUS 304 鋼では $\mathrm{MoO}_{4}{ }^{2-}, \mathrm{WO}_{4}{ }^{2-}, \mathrm{VO}_{3}{ }^{-}$及び $\mathrm{CrO}_{4}{ }^{2-}$ イオンは共に $2 \times 10^{-2} \mathrm{M}$ 以上で完全に TGSCC を防止する。

酸素酸イオンによる TGSCC 防止機構を検討するた め, $2 \times 10^{-1} \mathrm{M}$ 酸素酸イオンを含有する非脱気溶液中で の SUS 304 鋼のアノ一ド分極曲線を調查した結果を Fig. 9 飞示す。 $1,000 \mathrm{ppm} \mathrm{Cl}^{-}$イオン溶液のみの場合に は SUS 304 鋼の孔食電位は前にも述べたように -150 $\mathrm{mV}$ (vs. $\mathrm{Ag} / \mathrm{AgCl}$ ) である。酸素酸イオンを添加した場 合の $E_{\text {corr }}$ から判断すると $\mathrm{MoO}_{4}{ }^{2-}, \mathrm{WO}_{4}{ }^{2-}, \mathrm{VO}_{3}{ }^{-}$イ オン含有溶液中でのアノード分極曲線では $50 \sim 100 \mathrm{mV}$ 程度 $E_{\mathrm{corr}}$ が卑電位側にずれる。また孔食発生に帰因す 電流密度の上昇は認められず $\mathrm{Cl}^{-}$イオンを含有しない 溶液中でのアノード分極挙動 (Fig. 1) とほぼ同じで過 不働態電位領域に電流密度の極小值が存在し, それ以 後再び上昇する。この結果から特に注目している $\mathrm{MoO}_{4}{ }^{2-}$ イオンによるステンレス鋼の TGSCC 防止効 果は，(1)腐食電位を卑に移行させ，(2)孔食電位を著しく 高めることにより孔食発生を防止することが主原因であ ると考党られる。

$\mathrm{MoO}_{4}{ }^{2-}$ イオンの TGSCC に及ぼす影響を更に検討 するため SUS 304 鋼の定電位 SCC 試験を実施した。 試験時間は Table 2 の場合と同様に $500 \mathrm{~h}$ の自然浸漬 SCC 試験を実施した場合の電気量より各電位の保持時 間を計算した。試験溶液としては $1,000 \mathrm{ppm} \mathrm{Cl}^{-}+2 \times$
Table 3 Potentiostatic SCC test results of SUS 304 stainless steel in $1000 \mathrm{ppm} \mathrm{Cl}^{-}$containing water at $200^{\circ} \mathrm{C}$ with or without $\mathrm{MoO}_{4}{ }^{2-}$ (air-saturated, U-bend).

\begin{tabular}{|l|c|c|c|c|c|}
\hline $\begin{array}{c}\text { Applied } \\
\text { potential }\end{array}$ & $\begin{array}{c}0 \mathrm{mV} \text { for } \\
90 \mathrm{~min}\end{array}$ & $\begin{array}{c}250 \mathrm{mV} \text { for } \\
30 \mathrm{~min}\end{array}$ & $\begin{array}{c}500 \mathrm{mV} \text { for } \\
20 \mathrm{~min}\end{array}$ & $\begin{array}{c}61 \mathrm{mV} \text { for } \\
34 \mathrm{~min}\end{array}$ & $\begin{array}{c}720 \mathrm{mV} \text { for } \\
34 \mathrm{~min}\end{array}$ \\
\hline $\begin{array}{l}1000 \mathrm{ppm} \mathrm{Cl} \\
\text { containing water }\end{array}$ & $\begin{array}{c}\text { TGSCC. } \\
1700 \mu\end{array}$ & $\begin{array}{l}\mathrm{TGSCC} \\
1300 \mu\end{array}$ & $\begin{array}{c}\mathrm{TGSCC} \\
1000 \mu\end{array}$ & - & - \\
\hline $\begin{array}{l}1000 \mathrm{ppm} \mathrm{Cl} \mathrm{Cl}^{-} \mathrm{plus} \\
2 \times 10^{-1} \mathrm{M} \mathrm{Mo \textrm {O } _ { 4 } ^ { 2 - }} \\
\text { containing water }\end{array}$ & - & - & no SCC & no SCC & no SCC \\
\hline
\end{tabular}

$10^{-1} \mathrm{M} \mathrm{MoO}_{4}{ }^{2-}$ イオン溶液を使用し, 試験温度は $200^{\circ} \mathrm{C}$ 非脱気で実施した。試験結果を Table 3 亿示す。 $2 \times$ $10^{-1} \mathrm{MoO}_{4}{ }^{2-}$ イオン添加溶液では電位を $720 \mathrm{mV}$ まで 上昇させても TGSCC は発生しない。この結果から $\mathrm{Cl}^{-}$イオン含有高温水に $\mathrm{MoO}_{4}{ }^{2-}$ イオンを添加した溶 液では $\mathrm{MoO}_{4}{ }^{2-}$ イオンの TGSCC 抑制効果が電位的に 見て極めて強力であることがわかった。

そこで定電位下での SUS 304 鋼の表面皮膜の ESCA 分析を実施した結果を Fig. 10 亿示す。試験片は $200^{\circ} \mathrm{C}$,

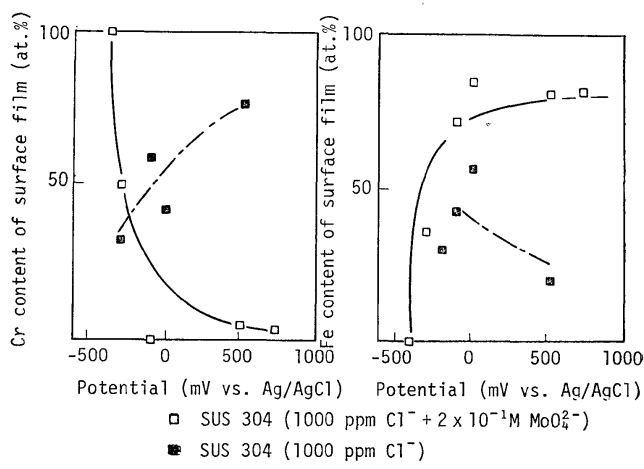

Fig. 10 Surface film analyses of SUS 304 stainless steel in water containing $1000 \mathrm{ppm}$ $\mathrm{Cl}^{-}$with or without $\mathrm{MoO}_{4}{ }^{2-}$ at $200^{\circ} \mathrm{C}$ by the ESCA.

非脱気の溶液中に $3 \mathrm{~h}$ 各電位に保持後表面皮膜の分析を 行った。表面皮膜中には Ni は洼とんど存在しなかっ た。 $1,000 \mathrm{ppm} \mathrm{Cl}^{-}$イオン溶液中では電位の上昇に伴っ て表面皮膜中の $\mathrm{Cr}$ 量は増大し, $\mathrm{Fe}$ 量は減少する。こ の $\mathrm{Cr}, \mathrm{Fe}$ は ESCA の結合エネルギーの解析結果から 水酸化物の状態であり, 腐食により生成された沈搌表面 皮膜であると考兄られる。1,000 $\mathrm{ppm} \mathrm{Cl}^{-}+2 \times 10^{-1} \mathrm{M}$ $\mathrm{MoO}_{4}{ }^{2-}$ イオン溶液中では電位が上昇すると過不働態電 位領域のため表面皮膜中の $\mathrm{Cr}$ 量は著しく減少し, $\mathrm{Fe}$ 量は増加する。この場合の $\mathrm{Cr}, \mathrm{Fe}$ の形態は $\mathrm{Cr}_{2} \mathrm{O}_{3}$ あ るいは $\mathrm{Fe}_{3} \mathrm{O}_{4}, \mathrm{Fe}_{2} \mathrm{O}_{3}$ の酸化物で, 緻密な不働態皮膜で あると考学られる。Mo は表面外層部にわずかに存在す る。な拈非脱気条件下での SUS 304 鋼の $E_{\text {corr }}$ は $-400 \mathrm{mV}$ であり, この場合の表面皮膜の金属成分は注 
とんぞ $\mathrm{Cr}$ である。この結果から $\mathrm{MoO}_{4}{ }^{2-}$ イオンの役 割りとしては表面皮膜外層部に吸着あるいは取りこまれ て, $\mathrm{Cl}^{-}$イオンによる表面皮膜の破壊を防止し, 内層部 に $\mathrm{Cr}, \mathrm{Fe}$ の酸化物不働態皮膜の生成を可能にして, ステンレス鋼の TGSCC 防止を行っていると考兄られ る。

\section{4. 考察}

$\mathrm{MoO}_{4}{ }^{2-}$ イオンを含む高温水溶液中の SUS 304 鋼の IGSCC 及び TGSCC 挙動を検討した結果, $\mathrm{MoO}_{4}{ }^{2-}$ イ オンの SCC 防止効果が著しいことが明らかとなった。 $\mathrm{MoO}_{4}{ }^{2-}$ イオンの IGSCC 防止機構は

1) 粒界 $\mathrm{Cr}$ 欠乏層部の溶解速度を $\mathrm{MoO}_{4}{ }^{2-}$ イオン がステンレス鋼表面皮膜の外層に吸着あるいは取りこま れて, 粒内の $\mathrm{Cr}$ 量 $18 \%$ の領域の溶解速度まで引き下
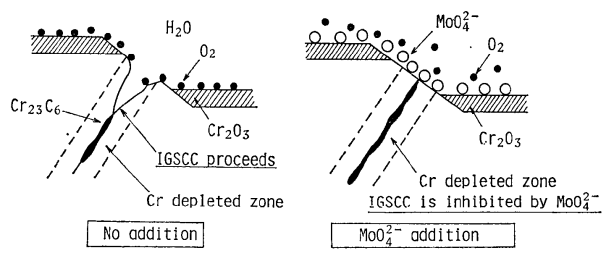

Fig. 11 Mechanism of IGSCC inhibition of stainless steels by oxyanions.

ゲることによる粒界選択溶解の抑制にあると考えられ る。この模式図をFig. 11 亿示す。

\section{TGSCC 防止機構は}

2) $\mathrm{MoO}_{4}{ }^{2-}$ イオンが IGSCC の場合と同様にステン レス鋼表面皮膜外層に吸着あるいは取りこまれ耐孔食性 を高める。すなわち(1)表面電位を孔食電位より卑に移行

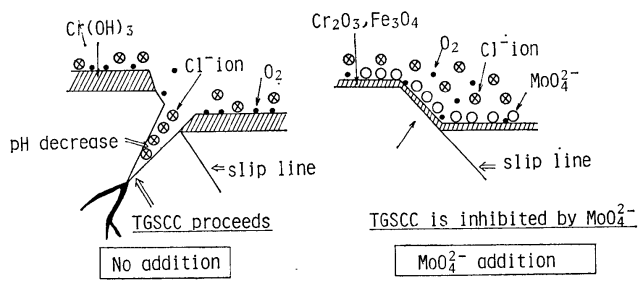

Fig 12 Mechanism of TGSCC inhibition of stainless steel by oxyanions.

させ，(2) $\mathrm{Cl}^{-}$イオンに対する孔食電位を著しく貴に上昇 させ実質的に孔食の発生を防止する。その結果孔食を起 点として発生する $\mathrm{Cl}^{-}$イオン含有高温水中の TGSCC 発生を抑制する。この模式図を Fig. 12 亿示す。

一方, Mo を含有するステンレス鋼の高温水中の耐 SCC 性は Mo を含有しないステンレス鋼に比較して良 好である。この原因の一因として，鋼中 $\mathrm{Mo}$ が $\mathrm{MoO}_{4}{ }^{2-}$ イオンとして溶液中に溶出し, 鋼表面の溶解反応に影響
を与光, $\mathrm{MoO}_{4}{ }^{2-}$ イオン含有高温水中の IGSCC 及び TGSCC 防止機構之同様の機構で SCC 発生を抑制す ると考兄られる。

\section{5. 結言}

SUS 304 鋼の酸素酸イオンを含む高温水溶液中のア， ード溶解と SCC 挙動を検討し，以下の結果を得た。

1) 鋭敏化 SUS 304 鋼の高温水中の IGSCC は $\mathrm{Cr}$ 欠乏層相当部である $12 \mathrm{Cr}-11 \mathrm{Ni} ， 8 \mathrm{Cr}-11 \mathrm{Ni}$ と粒内 相当部である SUS 304 鋼の不働態電流密度の差が大き くなる電位以上で発生する。

2) $\mathrm{MoO}_{4}{ }^{2-}, \mathrm{WO}_{4}{ }^{2-}, \mathrm{CrO}_{4}{ }^{2-}$ イオンを非脱気高温水 中に添加することにより鋭敏化 SUS 304 鋼の IGSCC を防止できる。

3) $\mathrm{MoO}_{4}^{2-}$ イオンによる鋭敏化 SUS 304 鋼の IGSCC 防止機構は $\mathrm{Cr}$ 久乏層部の溶解電流密度を粒内 の溶解電流密度まで減少させることによる粒界選択溶解 の抑制にあると考觉られる。

4) 溶体化 SUS 304 鋼の $\mathrm{Cl}^{-}$含有高温水中の TGSCC は孔食発生電位領域上り貴な電位領域で発生する。

5) $\mathrm{MoO}_{4}{ }^{2-}, \mathrm{VO}_{3}{ }^{-}, \mathrm{WO}_{4}{ }^{2-}, \mathrm{CrO}_{4}{ }^{2-}$ イオンを非脱気 $\mathrm{Cl}^{-}$含有高温水中に添加することにより, SUS 304 鋼の TGSCC を防止できる。

6) $\mathrm{MoO}_{4}{ }^{2-}$ イオンによる溶体化 SUS 304 鋼の TGSCC 防止機構は表面皮膜外層に吸着あるいは取りこ まれ，表面電位を孔食発生より卑飞移行させ，内層飞 $\mathrm{Cr}_{2} \mathrm{O}_{3}$ を主体とする酸化物不働態皮膜を形成し $\mathrm{Cl}^{-}$イ オンによる表面皮膜破壊を防止することにあると考兄ら 机る。

(Received September 18, 1984)

\section{文献}

1) J. M. Kolotyrkin: Corrosion, 19, 261 (1963).

2) O. Steenslard: Corrosion Prevention and Control, 15, 25 (1968).

3) J. Horvath \& H. H. Uhling: J. Electrochem. Soc., 115, 791 (1968).

4) E. A. Lizlovs \& A. P. Bond: J. Electrochem. Soc., 116, 574 (1969).

5) N. D. Stolica: Corr. Sci., 9, 205 (1969).

6) Z. Szklarska-Snialowska: Corrosion, 27, 223 (1971).

7) R. Bandy \& J. R. Cahoon: Corrosion, 33, 204 (1977).

8) E. A. Lizlovs: Localized Corrosion-Cause of Metal Failure, ASTM STP 516, 201 (1972).

9) R. J. Brigham: Corrosion, 30, 396 (1974).

10) H. Nagano, T. Kudo, Y. Inada \& M. Harada: The 19th "Journées des Aciers Speciaux", International Colloquim on Stainless steels, 
France (1980).

11) F. P. Ijsseling: Brit. Cor. J., 115, 51 (1980).

12) A. Garner: Corrosion, 37, 178 (1981).

13) A. Garner: Mater. Perform., 21, 9 (1982).

14) J. W. Johnson, C. H. Chi, C. K. Chen \& W. J. James: Corrosion, 21, 9 (1982).

15) E. A. Lizlovs: Corrosion, 32, 263 (1976).

16) T. Kodama and J. R. Ambrose: Corrosion, 33, 155 (1977).

17) J. N. Wanklyn: Corr. Sci., 21, 211 (1981).
18) K. Sugimoto and Y. Sawada: Corrosion, 32, 347 (1976).

19) M. Sakashita and N. Sato: Proceedings of the First Soviet-Japanese Seminar on Corrosion and Prevention of Metal, 173 (1979).

20) W. Robertson: J. Electrochem. Soc., 98, 94 (1951).

21) K. K. Chew and D. R. Gabe: Corrosion Prevention and Control, 26, 5 (1979). 